\begin{tabular}{|l|l|l|}
\hline \multicolumn{2}{|c|}{ PublisherInfo } \\
\hline \hline PublisherName & $:$ & BioMed Central \\
\hline \hline PublisherLocation & $:$ & London \\
\hline \hline PublisherImprintName & $:$ & BioMed Central \\
\hline \hline
\end{tabular}

\title{
Quality control of immunohistochemical assay of HER-2/neu
} expression

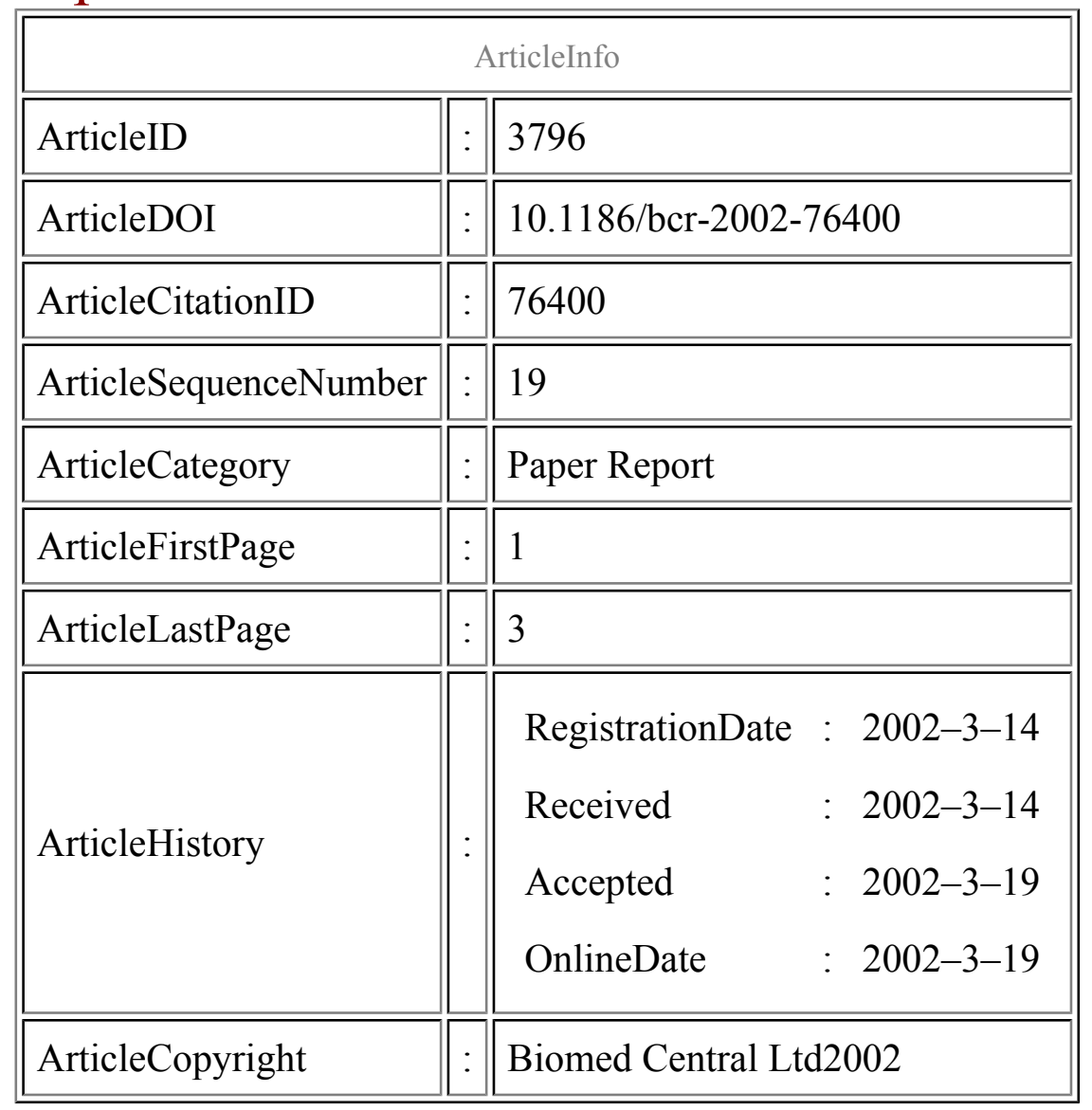




\begin{tabular}{|l|l|l||}
\hline ArticleGrants & $:$ & \\
\hline \hline ArticleContext & $:$ & 1305844 \\
\hline
\end{tabular}

George Skliris, ${ }^{\text {Aff1 }}$

Affl University of Leeds, UK

\section{Keywords}

\section{Breast and ovarian cell lines, FISH, HER-2/neu, immunohistochemistry}

\section{Context}

HER-2/neu (c-erb-2) gene encodes a membrane receptor related to the epidermal growth factor receptor and its amplification has been correlated with a shorter disease free interval in breast cancer patients. Recently, clinical trials have shown that treatment with an antibody can block growth of cells expressing HER-2/neu and prolong survival of patients. An immunohistochemical (IHC) test and fluorescence in situ hybridisation (FISH) are used to predict HER-2/neu status. IHC is economic to use and included in routine diagnostic services. However, IHC sensitivity varies between laboratories. In order to ensure reproducibility of results a standard control is needed so that day-to-day variation can be monitored. The objective of this study was to develop a control for HER-2/neu histochemical detection by investigating four breast and ovarian cell lines.

\section{Significant findings}

A $100 \%$ agreement between testing centres using FISH revealed that MDA-MB-453 and SKOV-3 cell lines showed HER-2/neu amplification, while BT-20 and MCF-7 were negative. SKOV-3 exhibited a score of 3+ HER-2/neu protein overexpression by IHC and gene amplification with FISH; in contrast, MCF-7 cells showed neither protein expression nor gene amplification (0 score). For BT-20 cells an $86 \%$ concordance $(6 / 7)$ was observed between a 0 or $1+$ score by IHC and no amplification detected by FISH, while $71 \%$ concordance between an HIC score of $2+$ and amplification detected by FISH was shown for MDA-MB-453. The sensitivity of the developed cell-line control was 3+,2+, 2+ and 0 with CB11 and 3+, 2+, 1+, 0 with the HercepTest or DAKO antibody (SKOV-3, MDA-MB-453, BT-20 and MCF-7 respectively). 


\section{Comments}

Composite blocks were produced, providing controls for immunohistochemical analysis of HER-2/ neu. These blocks were tested alongside commercially available kits in seven cancer centres in the UK and France. The developed control has the advantage of providing a graded series of expression for each of the $3+, 2+, 1+$ and 0 categories and can be implemented in the routine clinical setting. As a first step this control will help monitoring HER-2/neu assay sensitivity between various laboratories, despite the use of an antibody and antigen retrieval system. However, the development of a cell-line microarray in the near future will be advantageous in assisting with HER2/neu diagnosis.

\section{Methods}

Cell culture, IHC, FISH, antibodies (CB11 clone, HercepTest and DAKO polyclonal)

\section{Additional information}

Schnitt SJ and Jacobs TW: Current status of HER2 testing: caught between a rock and a hard place. Am J Clin Pathol 2001, 116: 806-810. (PubMed)

\section{References}

1. Rhodes A, Jasani B, Couturier J, McKinley M, Morgan J, Dodson A, Navabi H, Miller K, Balaton A: A formalin-fixed paraffin-processed cell line standard for quality control of immunohistochemical assay of HER-2/neu expression in breast cancer. Am J Clin Pathol. 2002, 117: 81-89.

This PDF file was created after publication. 